\title{
Uptake and distribution of bisphenol A and nonylphenol in vegetable crops irrigated with reclaimed water
}

\author{
Jian Lu, Jun Wu, Peter J. Stoffella, P. Chris Wilson* \\ Indian River Research and Education Center, University of Florida/IFAS, 2199 South Rock Road, Fort Pierce, FL 34945-3138, United States
}

\section{H I G H L I G H T S}

- BPA was more uniformly distributed between roots, stems, and leaves in lettuce.

- NP concentrations were highest at site of exposure for both crops.

- BPA concentrations were highest at site of exposure in tomatoes only.

- Estimated daily intake of BPA ranged from 8.9 to $62.9 \mu \mathrm{g}$.

- Estimated daily intake of NP ranged from 11.9 to $95.1 \mu \mathrm{g}$.

\section{A R T I C L E I N F O}

\section{Article history:}

Received 14 May 2014

Received in revised form 2 September 2014

Accepted 4 October 2014

Available online 22 October 2014

\section{Keywords:}

Endocrine-disrupting chemicals

Bisphenol A

BPA

Nonylphenol

NP

Bioaccumulation

\begin{abstract}
A B S T R A C T
The potential uptake and distribution of bisphenol A (BPA) and nonylphenol (NP) (from reclaimed irrigation water) in edible crops was investigated. BPA and NP were spiked into simulated reclaimed water at environmentally relevant concentrations. Two crops (lettuce, Lactuca sativa and tomato, Lycopersicon esculentum) were grown hydroponically in a greenhouse using the spiked irrigation water under two irrigation exposure scenarios (overhead foliar exposure and subsurface root exposure). BPA concentrations in tomato fruit were $26.6 \pm 5.8$ (root exposure) and $18.3 \pm 3.5$ (foliar exposure) $\mu \mathrm{g} \mathrm{kg}^{-1}$, while concentrations in lettuce leaves were $80.6 \pm 23.1$ (root exposure) and $128.9 \pm 17.4$ (foliar exposure) $\mu \mathrm{g} \mathrm{kg}^{-1}$. NP concentrations in tomato fruit were $46.1 \pm 6.6$ (root exposure) and $24.6 \pm 6.4$ (foliar exposure) $\mu \mathrm{g} \mathrm{kg}^{-1}$, while concentrations in lettuce leaves were $144.1 \pm 9.2$ (root exposure) and $195.0 \pm 16.9$ (foliar exposure) $\mu \mathrm{g} \mathrm{kg}^{-1}$. BPA was relatively mobile in lettuce plants regardless of exposure route. Limited mobility was observed for NP in both crops and BPA in tomatoes. The estimated daily intake of BPA and NP through consumption of vegetables irrigated with reclaimed water ranged from 8.9-62.9 to 11.9-95.1 $\mu \mathrm{g}$, respectively, depending on the exposure route.
\end{abstract}

(C) 2014 Elsevier B.V. All rights reserved.

\section{Introduction}

There is growing interest concerning the possible health threats posed by endocrine-disrupting chemicals (EDCs). EDCs are substances that interfere with hormone biosynthesis, metabolism, or action resulting in a deviation from normal homeostatic control or reproduction [1]. Among the many EDCs, bisphenol A (BPA) and nonylphenol (NP) have attracted public attention because of their potential negative effects on human and environmental health [1-4]. BPA is an industrial chemical used to manufacture a hard, clear plastic known as polycarbonate [5]. NP is a common biodegradation product of nonylphenol polyethoxylates (NPEOs) in wastewater [6-11]. Nonylphenol polyethoxylates (NPEOs) are one of the most widely used classes of non-ionic surfactants, encompassing more than $80 \%$ of the world market [12]. Their biodegradation product NP has many isomers with a phenol group and a linear (4-n-NP) or branched carbon (C) chain of nine C atoms $[6,13]$. Widespread occurrences of BPA and NP have been reported in various

\footnotetext{
* Corresponding author. Tel.: +1 (772) 468 3922x119; fax: +1 (772) 4685668.

E-mail address: pcwilson@ufl.edu (P.C.Wilson).
}

environments [3,7,8,11,14] and foodstuffs [13,15-17]. In a previous study [16], both BPA and NP were detected in many vegetables and fruits, indicating a significant potential exposure pathway for humans.

Reclaimed water is used for irrigation of agricultural crops worldwide due to increasing shortages of freshwater resources [18-22]. Reclaimed water is a source for many organic pollutants including pharmaceutical and personal care products in food crops such as soybean (Glycine max), pumpkins (Cucurbita pepo), and cucumber (Cucumis sativus) [23-25]. However, minimal information is available for the potential bioaccumulation of BPA and NP in edible crops irrigated with reclaimed water containing each. Reported BPA concentrations in effluents range from 0.01 to $370 \mu \mathrm{g} \mathrm{L}^{-1}$ [26]; whereas NP concentrations range from 0.2 to $330 \mu \mathrm{g} \mathrm{L}^{-1}[21,27]$. Both BPA and NP were frequently detected at relatively high concentrations in effluents [26-28], suggesting that irrigation with reclaimed water may be a pathway for BPA and NP entering into foodstuff.

This study evaluated the uptake, distribution, and mobility of BPA and NP in two popular crops irrigated with simulated reclaimed water containing BPA and NP (at environmentally relevant concentrations). Lettuce (Lactuca sativa) is grown worldwide for its edible leaves, while tomatoes (Lycopersicon esculentum) are grown for consumption of their fruit. Uptake and distribution were evaluated for two exposure scenarios, (1) foliar contact (simulating overhead irrigation methods) and (2) root 
contact (simulating subsurface and micro-sprinkler irrigation methods). Human exposures through consumption of vegetables (lettuce) and fruit (tomatoes) were estimated from the data collected.

\section{Materials and methods}

\subsection{Standards, reagents, chemicals, and plant materials}

Standards of NP (4-n-NP) ( $\geq 98 \%$ ), BPA ( $\geq 99 \%$ ), and $\beta$-estradiol 17 -acetate ( $\geq 99 \%$, served as surrogate) were purchased from Sigma-Aldrich (St Louis, MO). Isotope dilution standards (IDS) including ${ }^{13} \mathrm{C} 12-\mathrm{BPA}$ (ring- ${ }^{13} \mathrm{C} 12,99 \%$ ), and ${ }^{13} \mathrm{C} 6-4-\mathrm{n}-\mathrm{NP}$ (ring${ }^{13} \mathrm{C} 6,99 \%$ ) were purchased from Cambridge Isotope Laboratories, Inc. (Andover, MA). Standards were individually dissolved in acetonitrile at concentrations ranging from 1 to $10 \mathrm{mg} \mathrm{L}^{-1}$. Solvents including acetone, hexane, and methylene chloride were of pesticide grade while acetonitrile was of high performance liquid chromatography (HPLC) grade (Fisher Scientific, Pittsburgh, PA). Concentrated stock solutions were made for addition of the EDCs to irrigation water. The BPA stock water solution $\left(100 \mathrm{mg} \mathrm{L}^{-1}\right)$ was made by dissolving $200 \mathrm{mg}$ of BPA in $2000 \mathrm{~mL}$ of reagent grade water. The flask was sealed and placed on a magnetic stirrer for over $12 \mathrm{~h}$ to assure complete dissolution of the BPA. The NP stock solution ( $500 \mathrm{mg} \mathrm{mL}^{-1}$ ) was prepared in acetone. The stock solutions were stored at $\leq 4{ }^{\circ} \mathrm{C}$ before use. Lettuce (cv. Parris Island) seeds were obtained from Ferry-Morse Seed Co. (Fulton, KY, USA) while tomato (cv. Micro-Tom) seeds were kindly provided by Dr. Jay Scott at Gulf Coast Research and Education Center, University of Florida/IFAS.

\subsection{Exposures}

Lettuce (cv. Parris Island) and tomato (cv. Micro-Tom) seeds were sown in commercially available germination media (Conrad Fafard Inc., Agawam, MA, USA). Seedlings (30 d old, with two cotyledons and one true leaf) were transferred to a continuously aerated hydroponic culture system in a greenhouse. Typical temperatures in the greenhouse ranged from $30^{\circ} \mathrm{C}$ during daytime to $15^{\circ} \mathrm{C}$ during nights. The humidity in the greenhouse ranged from 40 to $85 \%$, reflecting levels outside. Each seedling was grown in an 11.4 -L container in 50\% Hoagland's nutrient solution [29]. The hydroponic nutrient solution was made by adding individual salts to aged, analyte-free tap water. The $\mathrm{pH}$ of the hydroponic solution ranged from 6.26 to 7.47 while electrical conductivity (EC) ranged from 1.99 to $2.34 \mathrm{mS} \mathrm{cm}^{-1}$ during the entire experiment. There were eight replicates for each treatment.

Irrigation source water (simulated reclaimed water) was spiked with BPA and NP at a target concentration of $50 \mu \mathrm{g} \mathrm{L}^{-1}$, which is a moderate environmentally relevant concentration based on previous reports $[27,28]$. Uptake of the EDCs into the plants was measured using two modes of exposure - root exposure (referring to irrigation of roots only, as with drip and subsurface irrigation methods) and foliar exposure (referring to overhead irrigation where irrigation water contacts the foliage). For the root exposure treatment, BPA and NP were spiked directly into the hydroponic nutrient solution. BPA and NP can be degraded efficiently by microflora in aqueous and soil environments, with half-lives of $1 d$ or less $[20,30]$. This short half-life was confirmed in the hydroponic system used in the current study based on several monitoring events using an HPLC equipped with a fluorescence detector (Waters Corporation, Milford, MA). The aeration system used in the hydroponic system likely enhanced biodegradation of the contaminants. For the foliar exposure treatment (overhead irrigation), BPA and NP were not spiked into the hydroponic nutrient solution. Instead, both compounds were dissolved in reagent grade water at a concentration of $50 \mu \mathrm{g} \mathrm{L}^{-1}$, followed by spraying (5-200 mL per day for lettuce; $2-30 \mathrm{~mL}$ per day for tomato) onto the leaves daily to simulate daily overhead irrigation with reclaimed water. The volume applied was based on the amount needed to wet all foliage and increased as the plants grew larger. Lettuce experiments ran for 30 days, while tomato experiments ran for 80 days reflecting the time to produce mature crops. The total spiking masses in the root exposure treatments for lettuce and tomato were 300 and $800 \mathrm{mg}$ per plant, respectively; while those in the foliar exposure treatment were 103.5 and $47.5 \mu \mathrm{g}$ per plant, respectively. Differences in amounts applied to each plant were due to the need for daily additions in the root exposure treatments, and the different volumes needed to wet the foliage for the foliar exposure treatments. Both root and foliar treatments included controls that received no BPA or NP. After the exposure periods, each plant was dissected into roots, leaves, stem, or fruit. Fresh weight of all plant fractions was recorded; followed by rinsing with deionized water, draining, freezing, and storage at $-20^{\circ} \mathrm{C}$ until extraction. All glassware and containers were washed with soapy water and rinsed with deionized water, dichloromethane and acetone before use to eliminate potential cross-contamination.

\subsection{Sample preparation and analysis}

To evaluate the potential bioaccumulation of BPA and NP in lettuce and tomato, six of the eight replicate plants in the greenhouse were randomly selected, extracted, and analyzed using isotope dilution gas chromatography with tandem mass spectrometry (GC-MS/MS) [16]. Briefly, plant samples $(5 \mathrm{~g})$ were mixed with $100 \mathrm{~mL}$ acetone after the IDS and surrogate ( $\beta$-estradiol 17acetate) was added. The surrogate was spiked at $50 \mu \mathrm{g} \mathrm{kg}^{-1}$. The samples were then homogenized in a glass research-grade blender and subjected to ultrasonic extraction, followed by vacuum filtration. The extracts were evaporated to dryness, redissolved in acetonitrile, followed by non-specific acid hydrolysis. The acidified solution with the target compounds was then extracted with methylene chloride. The extract was evaporated to dryness before being subjected to trimethylsilyl derivatization. The derivatized extracts were dried using UHP nitrogen and were then dissolved into $100 \mu \mathrm{L}$ of hexane for analysis. The derivatized extracts were analyzed using a Varian 3800 gas chromatograph connected to a Varian 4000 mass spectrometer with an internal electron ionization (EI) source (Agilent Technologies, Santa Clara, CA, USA). The target compounds were separated using a Rxi-5MS $(30 \mathrm{~m} \times 0.25 \mathrm{~mm}$, $0.25 \mu \mathrm{m}$ film thickness) capillary column (Restek Co., Bellefonte, PA, USA). The carrier gas (helium) was maintained at a constant flow rate of $1 \mathrm{mLmin}^{-1}$. Temperatures of the transfer line, trap, and manifold were held at $270^{\circ} \mathrm{C}, 150^{\circ} \mathrm{C}$, and $50^{\circ} \mathrm{C}$, respectively. Prepared extracts $(2 \mu \mathrm{L})$ were injected in splitless mode. Inlet temperature was held at $280^{\circ} \mathrm{C}$ and the oven temperature program was as follows: initial temperature, $130^{\circ} \mathrm{C}$; increasing to $280^{\circ} \mathrm{C}$ at $10^{\circ} \mathrm{C} \mathrm{min}-1$; hold at $280^{\circ} \mathrm{C}$ for $5 \mathrm{~min}$. The solvent delay was set to $5 \mathrm{~min}$. Quantification and confirmation of analytes was performed in multiple reaction monitoring (MRM) mode using matrix matched standards as described by Lu et al. [16]. MRM transitions for BPA and the internal standard ${ }^{13} \mathrm{C} 12$-BPA were $357>191+341$ and $369>197+353$, respectively; while those for NP (4-n-NP) and the ${ }^{13}$ C6-4-n-NP internal standard were $179>73$ and $185>73$, respectively. Method recoveries ranged from 96 to $99 \%$. The limits of detection (LOD) for BPA and NP were 0.03 and $0.1 \mu \mathrm{g} \mathrm{kg}^{-1}$, respectively. The limits of quantification (LOQ) for BPA and NP were 0.1 and $0.3 \mu \mathrm{g} \mathrm{kg}^{-1}$, respectively.

Samples of the spiked water (for root and foliar exposures) were collected on several days, centrifuged at 15,000 rpm, and analyzed using a Waters 2695 (Milford, MA, USA) Alliance high performance liquid chromatograph (HPLC) equipped with a Waters Carbamate Analysis column $(150 \times 3.9 \mathrm{~mm})$ (Milford, MA, USA) and 
a Waters 474 fluorescence detector. Binary gradients of acetonitrile and water composed the mobile phase. For BPA analysis, acetonitrile was increased from 40 to $58 \%$ within $4.5 \mathrm{~min}$. For NP analysis, acetonitrile was increased from 80 to $90 \%$ within $5.0 \mathrm{~min}$, with a $10 \mathrm{~min}$ hold ( $15 \mathrm{~min}$ total run). The mobile phase flow rate was $1.0 \mathrm{~mL} \mathrm{~min}^{-1}$. Excitation wavelength for BPA was $225 \mathrm{~nm}$ and the emission wavelength was $310 \mathrm{~nm}$. Excitation wavelength for NP was $280 \mathrm{~nm}$ and the emission wavelength was $310 \mathrm{~nm}$. Injection volume was $500 \mu \mathrm{L}$ and the column temperature was maintained at $35^{\circ} \mathrm{C}$. Method detection limits (MDLs) for BPA and NP were 0.1 and $0.5 \mu \mathrm{g} \mathrm{L}{ }^{-1}$, respectively.

\subsection{Data analysis}

Daily intake of BPA and NP was estimated by multiplying the average daily vegetable consumption by the concentrations of each in lettuce leaves or tomato fruit. In this study, the average daily vegetable intake was estimated to be $488 \mathrm{~g} \mathrm{~d}^{-1}$ (Per capita consumption of vegetables in 2010: $178 \mathrm{~kg} \mathrm{yr}^{-1}$ ) [31]. The distribution (\%) of each compound in plants was calculated by dividing the total masses in each tissue (i.e. roots, stem, leaves, fruit) by the total amount in the plants. Total mass in each tissue was calculated by multiplying the measured concentration by the fresh weight of each tissue; while the total mass in plants was calculated by adding the total mass of EDCs in each tissue of the plant together.

\section{Results}

BPA and NP were detected in different tissues of lettuce and tomato in both root and foliar exposure treatments (Fig. 1), suggesting that both compounds can be taken up by crops through both roots and leaves when present in reclaimed water irrigation.

\subsection{Uptake and distribution}

3.1.1. $B P A$

3.1.1.1. Lettuce. Exposure pathways influenced the partitioning behavior of BPA within lettuce plants. In the root exposure experiments, mean concentrations of BPA were highest in lettuce roots $\left(248.8 \pm 37.9 \mu \mathrm{g} \mathrm{kg}^{-1}\right)$, lowest in the stems $\left(27.4 \pm 3.6 \mu \mathrm{g} \mathrm{kg}^{-1}\right)$, and intermediate in the leaves $\left(80.6 \pm 23.1 \mu \mathrm{g} \mathrm{kg}^{-1}\right)$ (Fig. 1). Accounting for the mass of each respective tissue, total BPA content in each tissue type was $35.9 \pm 5.8 \mu \mathrm{g}$ (roots), $4.8 \pm 0.8 \mu \mathrm{g}$ (stems), and $26.0 \pm 6.0 \mu \mathrm{g}$ (leaves) (Fig. 2). On a percentage basis, $53.9 \%$ of the total mass taken up by the plant was distributed to the roots, while 39.0 and $7.1 \%$ was detected in the leaves and stems, respectively (Fig. 2).

In contrast, highest mean concentrations for the foliar exposure treatments were detected in the foliage $\left(128.9 \pm 17.4 \mu \mathrm{g} \mathrm{kg}^{-1}\right)$ and roots $\left(116.9 \pm 13.1 \mu \mathrm{g} \mathrm{kg}^{-1}\right)$ (Fig. 1$)$. As with the root exposures, concentrations in the stems $\left(52.8 \pm 15.1 \mu \mathrm{g} \mathrm{kg}^{-1}\right)$ were the lowest. The total mass of BPA detected in each tissue type, accounting for the mass of tissue, was $19.5 \pm 3.2 \mu \mathrm{g}$ (roots), $9.7 \pm 2.3 \mu \mathrm{g}$ (stems), and $48.0 \pm 6.1 \mu \mathrm{g}$ (leaves) (Fig. 2). On a percentage basis, $25.3 \%$ of the total mass taken up by the plant was distributed to the roots, while 62.2 and $12.6 \%$ was detected in the leaves and stems, respectively, indicating that the leaves were the primary sink (Fig. 2).

3.1.1.2. Tomato. As with lettuce, uptake occurred into all parts of the tomatoes, regardless of exposure pathway. Following root exposures, mean concentrations of BPA in tomato roots, stems,
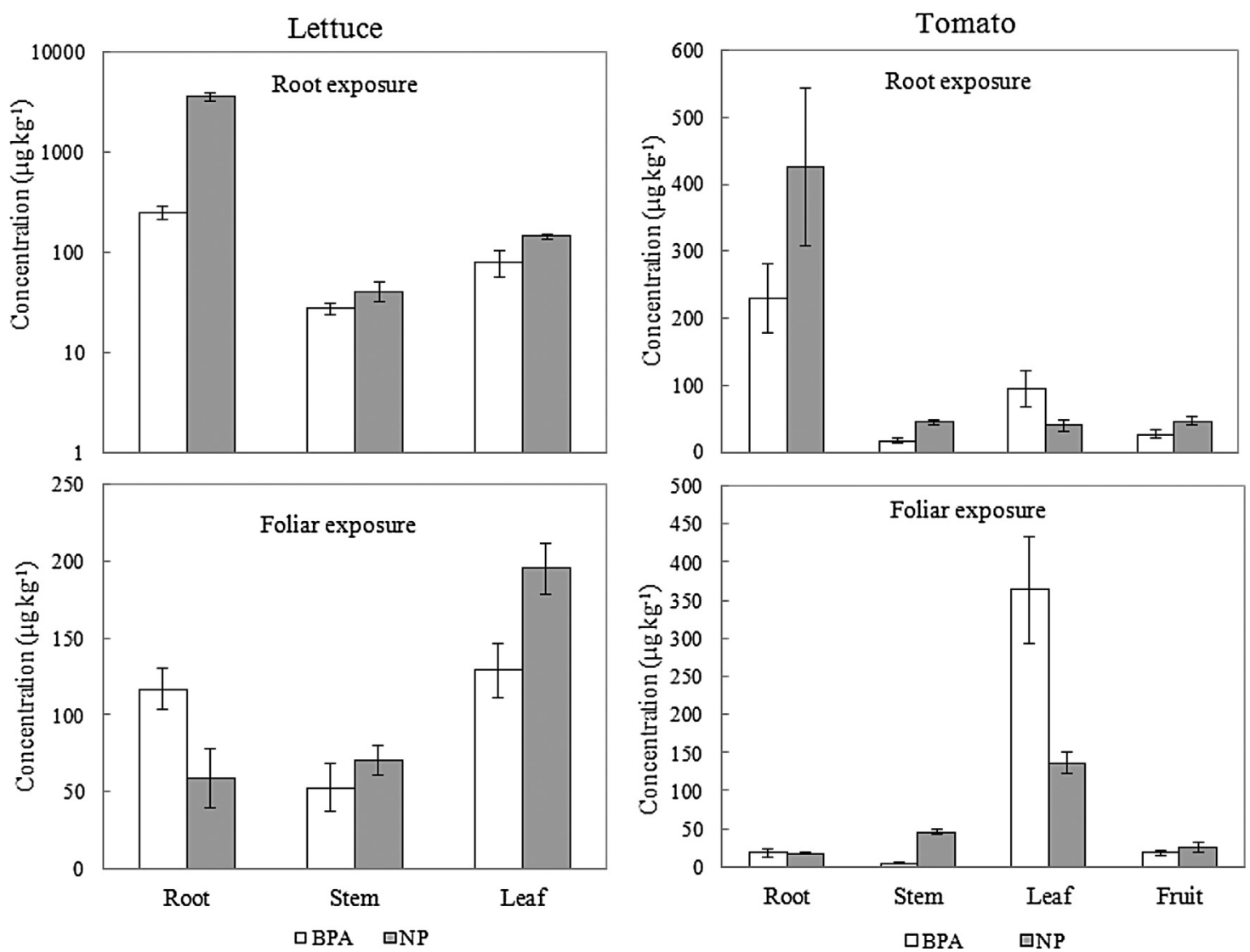

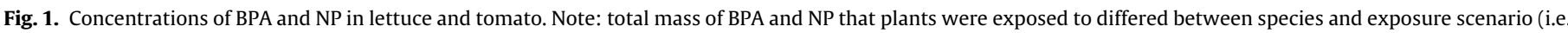
root exposures, lettuce ( $300 \mu \mathrm{g} / \mathrm{plant})$ and tomato $(800 \mu \mathrm{g} / \mathrm{plant})$; foliar exposures, lettuce (103.5 $\mu \mathrm{g} / \mathrm{plant})$ and tomato (47.5 $\mu \mathrm{g} / \mathrm{plant})$ ). 

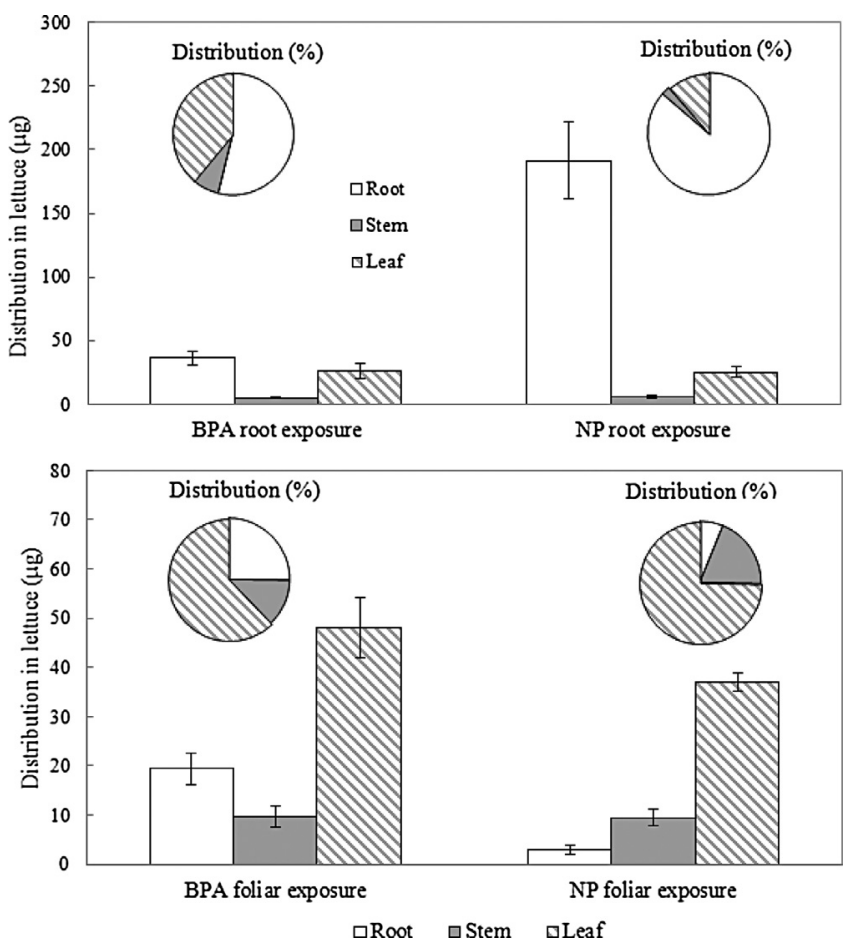

Fig. 2. Bisphenol-a (BPA) and nonylphenol (NP) mass ( $\mu \mathrm{g})$ and distribution (\%) in lettuce associated with root and foliar exposures. Plants were exposed to a total of $300 \mu \mathrm{g} /$ plant (root exposure) and $103.5 \mu \mathrm{g} /$ plant (foliar exposure).

leaves, and fruit were: $229.1 \pm 51.6 \mu \mathrm{g} \mathrm{kg}^{-1}, 16.2 \pm 3.4 \mu \mathrm{g} \mathrm{kg}^{-1}$, $94.4 \pm 27.8 \mu \mathrm{g} \mathrm{kg}^{-1}$, and $26.6 \pm 5.8 \mu \mathrm{g} \mathrm{kg}^{-1}$, respectively (Fig. 1). Accounting for the mass of each tissue, total mass detected in each was $8.9 \pm 1.6 \mu \mathrm{g}$ (roots), $2.3 \pm 0.4 \mu \mathrm{g}$ (fruit), $1.9 \pm 0.3 \mu \mathrm{g}$ (leaves), and $0.2 \pm 0.1 \mu \mathrm{g}$ (stems)(Fig. 3). On a percentage basis, these masses
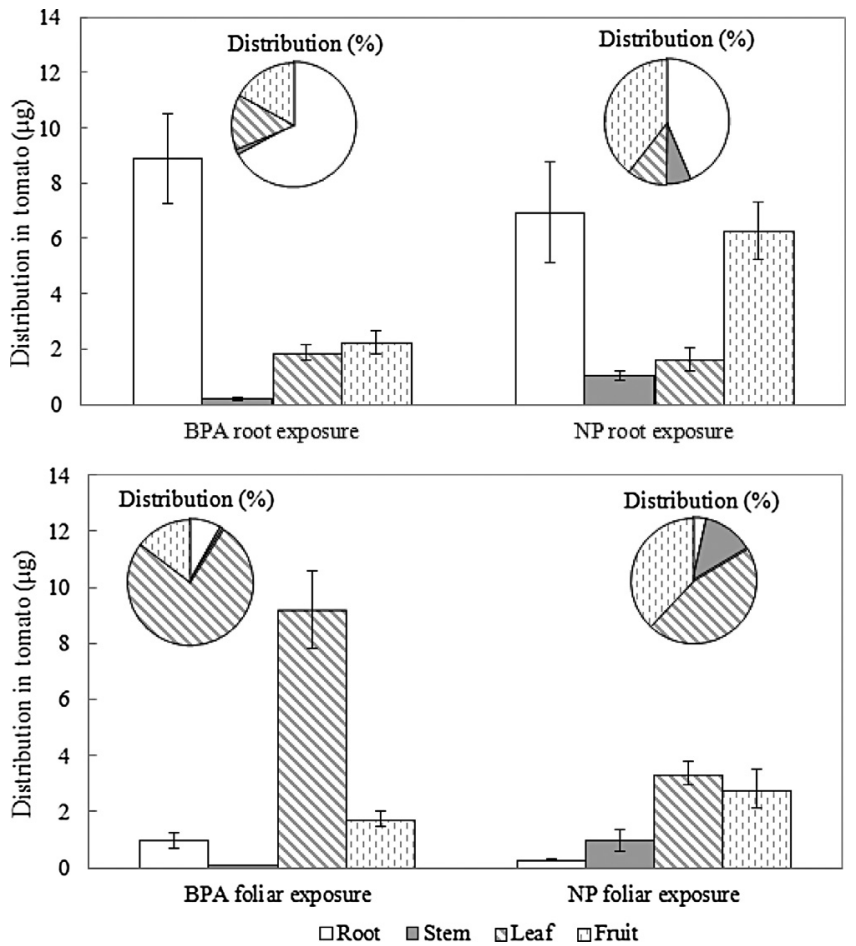

Fig. 3. Bisphenol-a (BPA) and nonylphenol (NP) mass ( $\mu \mathrm{g})$ and distribution (\%) in tomato associated with root and foliar exposures. Plants were exposed to a total of $800 \mu \mathrm{g} /$ plant (root exposure) and $47.5 \mu \mathrm{g} /$ plant (foliar exposure). equate to $67.1 \%$ (roots), $17.0 \%$ (fruit), $14.2 \%$ (leaves), and $1.7 \%$ (stems) of the total mass taken up by the plants (Fig. 3).

In contrast, BPA concentrations in each respective tissue following foliar exposures were: $18.2 \pm 5.3 \mu \mathrm{g} \mathrm{kg}^{-1}$ (roots), $4.9 \pm 2.0 \mu \mathrm{g} \mathrm{kg}^{-1} \quad$ (stems), $\quad 363.3 \pm 69.3 \mu \mathrm{g} \mathrm{kg}^{-1}$ (leaves), and $18.3 \pm 3.5 \mu \mathrm{g} \mathrm{kg}^{-1}$ (fruit) (Fig. 1). The total mass in each tissue type was: $1.0 \pm 0.3 \mu \mathrm{g}$ (roots), $0.1 \pm 0.03 \mu \mathrm{g}$ (stems), $9.2 \pm 1.4 \mu \mathrm{g}$ (leaves), and $1.8 \pm 0.3 \mu \mathrm{g}$ (fruit) (Fig. 3). These masses equate to $8.2 \%$ (root), $0.7 \%$ (stems), $76.5 \%$ (leaves), and $14.6 \%$ (fruit) of the total mass taken up by the plants, indicating that leaves were the dominant sink (Fig. 3).

\subsection{2. $N P$}

3.1.2.1. Lettuce. In the root exposure experiments, concentrations of NP were $3537.2 \pm 325.5 \mu \mathrm{g} \mathrm{kg}^{-1}$ (roots), $41.3 \pm 9.0 \mu \mathrm{g} \mathrm{kg}^{-1}$ (stems), and $144.1 \pm 9.2 \mu \mathrm{g} \mathrm{kg}^{-1}$ (leaves) (Fig. 1). Accounting for the mass of each tissue type, the total mass of NP in each was $191.3 \pm 30.1 \mu \mathrm{g}$ (roots), $5.1 \pm 1.3 \mu \mathrm{g}$ (stems), and $25.2 \pm 4.1 \mu \mathrm{g}$ (leaves) (Fig. 2). As a percentage of the total NP taken up by the plants, these masses equate to $86.3 \%$ (roots), $2.3 \%$ (stems), and $11.4 \%$ (leaves), indicating that the roots are the primary sink (Fig. 2).

In contrast, concentrations of NP in tissues from the foliar exposure treatments were $58.9 \pm 19.4 \mu \mathrm{g} \mathrm{kg}^{-1}$ (roots), $70.5 \pm 9.3 \mu \mathrm{g} \mathrm{kg}^{-1}$ (stems), and $195.0 \pm 16.9 \mu \mathrm{g} \mathrm{kg}^{-1}$ (leaves) (Fig. 1). The total mass in each tissue type, accounting for tissue mass, was: $3.0 \pm 0.9 \mu \mathrm{g}$ (roots), $9.5 \pm 1.6 \mu \mathrm{g}$ (stems), and $37.0 \pm 1.8 \mu \mathrm{g}$ (leaves) (Fig. 2). These masses equate to $6.2 \%$ (root), $19.2 \%$ (stems), and $74.6 \%$ (leaves) of the total mass taken up by the plants, indicating that leaves were the dominant sink (Fig. 2).

3.1.2.2. Tomato. NP was also detected in all tissues of tomatoes, regardless of irrigation exposure method. Concentrations in tissues from the root exposure treatment were $425.5 \pm 117.2 \mu \mathrm{g} \mathrm{kg}^{-1}$ (roots), $44.4 \pm 3.0 \mu \mathrm{g} \mathrm{kg}^{-1}$ (stems), $39.4 \pm 8.5 \mu \mathrm{g} \mathrm{kg}^{-1}$ (leaves), and $46.1 \pm 6.6 \mu \mathrm{g} \mathrm{kg}^{-1}$ (fruit) (Fig. 1). These concentrations, accounting for tissue mass, equate to $6.9 \pm 1.8 \mu \mathrm{g}$ (roots), $1.1 \pm 0.2 \mu \mathrm{g}$ (stems), $1.6 \pm 0.4 \mu \mathrm{g}$ (leaves), and $6.3 \pm 1.0 \mu \mathrm{g}$ (fruit) (Fig. 3). These masses equate to $43.6 \%$ (root), $6.7 \%$ (stems), $10.2 \%$ (leaves), and $39.5 \%$ (fruit) of the total mass taken up by the plants, indicating that roots and fruit were dominant sinks (Fig. 3).

In contrast, concentrations from the foliar exposure treatments were: $17.7 \pm 1.9 \mu \mathrm{g} \mathrm{kg}^{-1}$ (roots), $45.3 \pm 3.0 \mu \mathrm{g} \mathrm{kg}^{-1}$ (stems), $135.9 \pm 13.7 \mu \mathrm{g} \mathrm{kg}^{-1}$ (leaves), and $24.6 \pm 6.4 \mu \mathrm{g} \mathrm{kg}^{-1}$ (fruit) (Fig. 1). Accounting for the mass of each tissue, total mass detected in each was $0.3 \pm 0.03 \mu \mathrm{g}$ (roots), $1.0 \pm 0.4 \mu \mathrm{g}$ (stems), $3.3 \pm 0.4 \mu \mathrm{g}$ (leaves), and $2.8 \pm 0.7 \mu \mathrm{g}$ (fruit) (Fig. 3). On a percentage basis, these masses equate to $3.4 \%$ (roots), $38.0 \%$ (fruit), $45.6 \%$ (leaves), and $13.0 \%$ (stems) of the total mass taken up by the plants, indicating dominant distribution to leaves and fruit (Fig. 3).

\section{Discussion}

The uptake and distribution of BPA and NP (from simulated reclaimed irrigation water) into edible crops was observed. BPA $\left(\log K_{\mathrm{ow}}=3.40\right.$, water solubility $\left.=300 \mathrm{mg} \mathrm{L}^{-1}\right)$ [32,33] and NP $\left(\log K_{\text {ow }}=4.48\right.$, water solubility $\left.=4.9 \mathrm{mg} \mathrm{L}^{-1}\right)[34]$ were more water soluble than the traditional hydrophobic organic compounds such as pentachlorophenol $\left(\log K_{\mathrm{ow}}=5.12\right)$ and pyrene $\left(\log K_{\mathrm{ow}}=4.88\right)$ which are relatively immobile past the roots (evaluated root exposure only) [35]. According to Dettenmaier et al. [35] the uptake of organic pollutants through crops (soybean and tomato) almost ceased when the $\log K_{\mathrm{ow}}$ of the chemical is greater than 4.8. Exposure pathway (irrigation method) significantly influenced BPA and NP distribution in both crops. In both cases, the exposed tissues (roots or foliage) had the highest mass of each contaminant. However, interestingly both compounds were mobile to a limited extent 
within the plants (Figs. 1-3). Of the two exposure pathways, exposure of the foliage resulted in higher loadings of BPA and NP in the plant, relative to the root exposure pathway.

As a percentage of the total mass applied to the foliage in irrigation water, $74.6 \%$ and $47.9 \%$ of the BPA and NP was detected within the lettuce plants (whole), respectively; while $25.3 \%$ and $15.5 \%$ of each were accounted for in the tomatoes, respectively. It is difficult to accurately estimate uptake efficiency for both compounds in the root exposure treatments due to their instability in the hydroponic system. Previous studies have reported that BPA and NP can quickly degrade in aqueous and soil environments due to microbial action $[20,30]$, similar to this study. Ignoring the instability issue, the total mass uptake ranged from $0.002 \%$ (tomatoes) to $0.02 \%$ (lettuce, BPA) and $0.07 \%$ (lettuce, NP) of the total amount of both contaminants applied to both crops, with roots containing the highest concentrations of each. These results support those of Dodgen et al. [36], who also reported maximum accumulation of BPA and NP in roots of lettuce and collards grown hydroponically, with minimal transport into aerial portions of the plants. These results indicate that uptake of both compounds by the plants is more efficient with foliar exposures, relative to root-only exposures. Interestingly, significant redistribution of BPA through the stems and into the roots was observed when it was applied to the foliar treatments, resulting in relatively uniform concentrations in the leaves $(128.9 \pm 17.4 \mu \mathrm{g} / \mathrm{kg})$ and roots $(116.9 \pm 13.1 \mu \mathrm{g} / \mathrm{kg})$ of the plants (Fig. 1). However, when corrected for total mass of tissues, more BPA accumulated in the leaves (62\% of BPA taken up, Fig. 2). Similarities in NP concentrations were not observed, likely due to its much greater hydrophobicity. This transport pathway was likely associated with symplastic transport of BPA conjugated to carbohydrates. Lu et al. [16] reported higher analytical yields of BPA and several other contaminants from vegetables and fruit when plant tissues were subjected to a hydrolysis step, presumably due to hydrolysis of carbohydrate-contaminant bonds.

Results from this study are useful for estimating potential human exposures through the consumption of vegetables and fruit irrigated with reclaimed water containing BPA and NP. Assuming per capita vegetable consumption of $488 \mathrm{~g} \mathrm{~d}^{-1}$ [31] and that the mean concentrations of EDCs in lettuce leaves are representative of all vegetables, the daily intake of BPA and NP through consumption would range from 13.0 to $70.3 \mu \mathrm{g}$ based on the data from the root exposure treatment (common root irrigation culture system); and from 8.9 to $95.1 \mu \mathrm{g}$ for foliar-applications of reclaimed water. Assessment of risks to human health is beyond the scope of this study given the current uncertainty and lack-of-agreement associated with effects-thresholds for human health.

\section{Conclusions}

This research demonstrated the movement of BPA and NP (at environmentally relevant concentrations) into edible crops following root and foliar exposures simulating subsurface and overhead irrigation techniques using water containing the two compounds. Concentrations of nonylphenol in both crops tended to be greatest at the site of exposure, with some redistribution within the plants. In contrast, BPA concentrations in lettuce tended to be distributed more evenly between roots and leaves, regardless of exposure route, with less redistribution in the tomatoes. However, uptake into the aerial plant organs was more efficient through foliar contact. For this reason, exposure of consumers to these contaminants may be minimized by limiting contact of reclaimed water with the aerial portions of crops. These results highlight the individual species-contaminant relationships associated with potential uptake and redistribution. Further research is needed to better define these relationships using a wider array of chemical properties in order to develop models for predicting potential contamination of edible crops. These results likely represent a worse-case scenario for plant exposures. In production systems, the contaminants would be exposed to, and interact with, soil components and more diverse microbial populations, which could significantly reduce their availability for uptake by the crop plants.

\section{Acknowledgments}

We thank the USDA National Institute of Food and AgricultureAgriculture and Food Research Initiative (NIFA-AFRI Grant No. 2011-67019-21119) for funding and the reviewers for their valuable suggestions and comments concerning the manuscript.

\section{References}

[1] E. Diamanti-Kandarakis, J.P. Bourguignon, L.C. Giudice, R. Hauser, G.S. Prins, A.M. Soto, R.T. Zoeller, A.C. Gore, Endocrine-disrupting chemicals an endocrine society scientific statement, Endocr. Rev. 30 (2009) 293-342.

[2] D. Balabanič, M. Rupnik, A.K. Klemenčič, Negative impact of endocrinedisrupting compounds on human reproductive health, Reprod. Fertil. Dev. 23 (3) (2011) 403-416.

[3] K. Ikehata, Y. Liu, R. Sun, Health effects associated with wastewater treatment, reuse, and disposal, Water Environ. Res. 81 (2009) 2126-2146.

[4] A.M. Soto, C. Sonnenschein, Environmental causes of cancer: endocrine disruptors as carcinogens, Nat. Rev. Endocrinol. 6 (2010) 363-370.

[5] FDA. (Food and Drug Administration) 2012, http://www.fda.gov/newsevents/ publichealthfocus/ucm064437.htm.

[6] J. Lu, Q. Jin, Y. He, J. Wu, Biodegradation of nonylphenol polyethoxylates under $\mathrm{Fe}(\mathrm{III})$-reducing conditions, Chemospehre 69 (2007) 1047-1054.

[7] J. Lu, Q. Jin, Y. He, J. Wu, W. Zhang, J. Zhao, Biodegradation of nonylphenol polyethoxylates by denitrifying activated sludge, Water Res. 42 (2008) 1075-1082.

[8] J. Lu, Q. Jin, Y. He, J. Wu, W. Zhang, J. Zhao, Biodegradation of nonylphenol polyethoxylates under sulfate-reducing conditions, Sci. Total Environ. 399 (2008) 121-127.

[9] J. Lu, Q. Jin, Y. He, J. Wu, W. Zhang, J. Zhao, Anaerobic degradation behavior of nonylphenol polyethoxylates in sludge, Chemosphere 71 (2008) 345-351.

[10] J. Lu, Y. He, J. Wu, Q. Jin, Aerobic and anaerobic biodegradation of nonylphenol ethoxylates in estuary sediment of Yangtze River, China, Environ. Geol. 57 (2009) 1-8.

[11] C.A. Staples, J.B. Williams, R.L. Blessing, P.T. Varineau, Measuring the biodegradability of nonylphenol ether carboxylates, octylphenol ether carboxylates, and nonylphenol, Chemosphere 38 (1999) 2029-2039.

[12] A.M. Warhurst, An Environmental Assessment of Alkylphenol Ethoxylates and Alkylphenols, Friends of the Earth Scotland, Edinburgh, Scotland, 1995, pp. 44

[13] K. Guenther, V. Heinke, B. Thiele, E. Kleist, H. Prast, T. Raecker, Endocrine disrupting nonylphenols are ubiquitous in food, Environ. Sci. Technol. 36 (2002) 1676-1680.

[14] B.D. Stanford, H.S. Weinberg, Isotope dilution for quantitation of steroid estrogens and nonylphenols by gas chromatography with tandem mass spectrometry in septic, soil, and groundwater matrices, J. Chromatogr. A 1176 (2007) 26-36.

[15] L. Grumetto, D. Montesano, S. Seccia, S. Albrizio, F. Barbato, Determination of bisphenol A and bisphenol B residues in canned peeled tomatoes by reversedphase liquid chromatography, J. Agric. Food Chem. 56 (2008) 10633-10637.

[16] J. Lu, J. Wu, P.J. Stoffella, P.C. Wilson, Analysis of bisphenol A, nonylphenol, and natural estrogens in vegetables and fruits using gas chromatography-tandem mass spectrometry, J. Agric. Food Chem. 61 (2013) 84-89.

[17] A. Schecter, N. Malik, D. Haffner, S. Smith, T.R. Harris, O. Paepke, L. Birnbaum, Bisphenol A in US food, Environ. Sci. Technol. 44 (2010) 9425-9430.

[18] A.C. Chang, A.L. Page, T. Asano, Developing Human Health-Related Chemical Guidelines for Reclaimed Water and Sewage Sludge Application in Agriculture, World Health Organization, Geneva, Switzerland, 2002.

[19] N.T.L. Huong, O. Masami, L. Li, T. Higashi, M. Kanayama, Heavy metal contamination of river sediments in Vietnam, Water Manage. 163 (2010) 111-121.

[20] G.M. Klecka, S.J. Gonsior, R.J. West, P.A. Goodwin, D.A. Markham, Biodegradation of bisphenol $A$ in aquatic environments: river die-away, Environ. Toxicol. Chem. 12 (2001) 2725-2735.

[21] M.H. Lim, Fate of Wastewater-derived Contaminants in Surface Waters, ProQuest LLC, Ann Arbor, MI, 2009, pp. 10.

[22] H. Yao, J. Lu, X. Yuan, J. Wu, J. Zhao, X. Yu, Y. Zhou, Concentrations, bioavailability, and spatial distribution of soil heavy metals in a long-term wastewater irrigation area in North China, CLEAN-Soil Air Water 42 (3) (2014) 331-338.

[23] N. Aryal, D. Reinhold, Phytoaccumulation of antimicrobials from biosolids: impacts on environmental fate and relevance to human exposure, Water Res. 45 (2011) 5545-5552.

[24] M. Shenker, D. Harush, J. Ben-Ari, B. Chefetz, Uptake of carbamazepine by cucumber plants - a case study related to irrigation with reclaimed wastewater, Chemosphere 82 (2011) 905-910. 
[25] C. Wu, A.L. Spongberg, J.D. Witter, M. Fang, K.P. Czajkowski, Uptake of pharmaceutical and personal care products by soybean plants from soils applied with biosolids and irrigated with contaminated water, Environ. Sci. Technol. 44 (2010) 6157-6161.

[26] Y.Q. Huang, C.K.C. Wong, J.S. Zheng, H. Bouwman, R. Barra, B. Wahlström, L. Neretin, M.H. Wong, Bisphenol A (BPA) in China: a review of sources, environmental levels, and potential human health impacts, Environ. Int. 42 (2012) 91-99.

[27] M.A. Blackburn, M.J. Waldock, Concentrations of alkylphenols in rivers and estuaries in England and Wales, Water Res. 29 (1995) 1623-1629.

[28] H.B. Lee, T.E. Peart, Determination of bisphenol A in sewage effluent and sludge by solid-phase and supercritical fluid extraction and gas chromatography/mass spectrometry, J. Assoc. Anal. Commun. Int. 83 (2000) 290-298.

[29] D.R. Hoagland, D.I. Arnon, The water-culture method for growing plants without soil, Calif. Agr. Expt. Sta. Circ. (1950) 347.

[30] Z. Mao, X.Zheng, Y.Zhang, X. Tao, Y. Li, W. Wang, Occurrence and biodegrdation of nonylphenol in the environment, Int. J. Mol. Sci. 13 (2012) 491-505.
[31] USDA (United States Department of Agriculture), National Agricultural Statistics Service. Agricultural Statistics, United States Government Printing Office, Washington D.C., 2012, pp. 2049.

[32] I.T. Cousins, C.A. Staples, G.M. Klecka, D. Mackay, A multimedia assessment of the environmental fate of bisphenol A, Hum. Ecol. Risk Assess. 8 (2002) 1107-1135.

[33] C.A. Staples, P.B. Dorn, G.M. Kleck, S.T. Oblock, L.R. Harris, A review of the environmental fate, effects, and exposures of bisphenol A, Chemosphere 36 (1998) 2149-2173.

[34] A. Soares, G. Guieysse, B. Jefferson, E. Cartmell, J.N. Lester, Nonylphenol in the environment: a critical review on occurrence, fate, toxicity and treatment in wastewaters, Environ. Int. 34 (2008) 1033-1049.

[35] E.M. Dettenmaier, W.J. Doucette, B. Bugbee, Chemical hydrophobicity and uptake by plant roots, Environ. Sci. Technol. 43 (2009) 324-329.

[36] L.K. Dodgen, J. Li, D. Parker, J.J. Gan, Uptake and accumulation of four PPCP/EDCs in two leafy vegetables, Environ. Pollut. 182 (2013) 150-156. 